\title{
表面透気試験を用いた中性化に伴う鋼材腐食の 耐久性設計と検査の連係に関する一考察
}

\author{
加藤 佳孝 1 ・早川 健司2 \\ 1正会員 東京理科大学准教授 理工学部土木工学科（†278-8510 千葉県野田市山崎2641） \\ E-mail: katoyosh@rs.tus.ac.jp \\ 2正会員 東急建設（株） 土木技術部（252-0244 神奈川県相模原市中央区田名3062-1） \\ E-mail: hayakawa.kenji@tokyu-cnst.co.jp
}

\begin{abstract}
本研究では, 中性化に伴う鋼材腐食において, 設計一施工一検查一維持管理の有機的な連係をめざし, コンクリートの中性化速度係数と非破壞試験である表面透気試験の測定結果との関係を整理した。ささらに, 試験室の検討ではあるが，普通コンクリートの表層透気係数は，水セメント比，ブリーディング量および 1層の打込み高さの関数として表現可能であることを示した. 提案手法を用いて, 配合選定（水セメント 比とブリーディング量の選定），検査の方法，および構造物の初期性能に関して考察した.
\end{abstract}

Key Words : surface air-permeability, bleeding, durability design, carbonation, inspection

\section{1. はじめに}

2007年制定コンクリート標準示方書（以下，示方書） [設計編 : 本編] 1)では，中性化に伴う鋼材腐食に対す る照査（以下, 中性化の照査）として, 中性化深さの設 計值と鋼材腐食発生限界深さに対する比に構造物係数を 乗じた值が，1.0以下であることを確かめることにより 行ってよいとされている. 照査で用いる中性化速度係数 は，実験や既存のデータに基づいて定めることが原則と されているが，解説に参考として，有効水結合材比の一 次関数が掲載されている. 確かに, 有効水結合材比は, 中性化速度係数に最も影響を及ぼす因子であると考えら れるが，同一有効水結合材比であっても，コンクリート の構成材料割合が異なれば，中性化速度係数が変化する ことも予想される. 既往の研究2)では，同一水セメント 比で単位水量を変化させた場合，単位水量の増加に伴い 表層コンクリートの透気性が増大し，その透気性はブリ 一ディングと密接な関係があることが指摘されている.

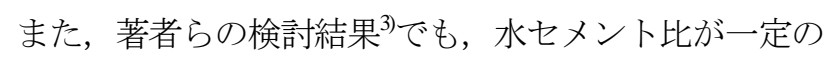
条件下では，ブリーディング量とコンクリートの表層透 気係数の相関が確認されており，ブリーディング量が表 層コンクリートの透気性や中性化速度係数に及ぼす影響 を定量的に評価する必要があると考えられる。

ここで，検査に関する示方書の記述に着目すると，示

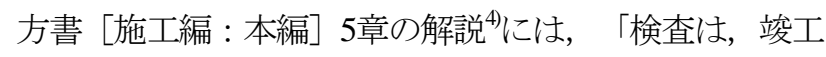

したコンクリート構造物の性能を直接的に検査すること が理想である.」とあり, 直接的に性能を検査すること の重要性が指摘されている.さらに, 示方書改訂小委員 会報告書5にも，「コンクリート構造物の耐久性能に関 して, 設計一施工一検査一維持管理の一連の有機的な連 係を整理すれば，コンクリートの特性值に基づいた耐久 設計を行い，コンクリートの特性值の要求を満足させる ことができるように適切な配合設計と入念な施工を行い， 耐久設計において定めたコンクリートの特性值とかぶり の実現状況を検査し，完成した構造物の初期品質・初期 性能を踏まえた維持管理計画の確認・見直しを適切に行 うことが理想形ではなかろうか.」との記述があり，既 報のでも同様にその重要性が指摘されている。これらの 記述から, 現状では, 中性化速度係数などのコンクリー トの特性值に基づいた，設計一施工一検査一維持管理の 連係が必ずしも十分ではないことがわかる.

本研究では，中性化に伴う鋼材腐食において，設計一 施工一検査一維持管理の有機的な連係をめざし, 表面透 気試験を用いた設計と検査の連係について考察する.さ らに，ブリーディングが表層コンクリートの透気性に及 ぼす影響を実験的に把握し，ブリーディングの影響を考 慮した設計の考え方も整理する. 本研究では，既往の研 究および著者らがこれまで実施し公表してきた実験結果 を用いて，設計と検査の連係について考察することを主 眼とするため, 詳細な実験条件および結果は, 各々の参 
考文献を参照されたい.

\section{2. 検討内容の整理}

\section{（1） 実構造物の中性化速度係数の計測の代替手法}

設計一施工一検査一維持管理の連係を達成するために は，コンクリートの中性化速度係数と実構造物で計測可 能な手法の計測值との関連付けが必要不可欠となる．検 査の段階で実構造物の中性化速度係数を直接計測できる 手法が望ましいが，現状では存在せず，透気性試験との 関連付けが現実的な方法と思われる. 実構造物における コンクリートの透気性の計測に関する研究は，比較的古

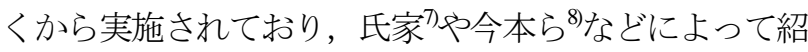
介されている. 本研究では透気性試験として, 非破壊で あり，これまでいくつかの研究機関で検討され，比較的 信頼性が高いと言われているダブルチャンバー方式の Torrent法9による表面透気試験の結果を用いて, 中性化 速度係数との関係を整理する，本試験は，真空ポンプを 用いたチャンバーの吸引によってチャンバー内部を設定 值（30hPa）まで減圧し，その後内部の気圧が復圧して いく過程から，表層透気係数を式(1)により求める方法 である. チャンバー全体の直径は $100 \mathrm{~mm}$ で, 計測対象と なる内部チャンバーの直径は $50 \mathrm{~mm}$ である. なお，対象 となるコンクリートの空隙率を, 測定時に正確に知るこ とは難しいため, 通常, $0.15 \mathrm{~m}^{3} / \mathrm{m}^{3}$ が想定值として用いら れている.

$$
k T=\left(\frac{V_{c}}{A}\right)^{2} \frac{\mu}{2 \varepsilon P_{a}}\left[\frac{\ln \left(\frac{P_{a}+\Delta P}{P_{a}-\Delta P}\right)}{\sqrt{t}-\sqrt{t_{0}}}\right]^{2}
$$

ここに, $k T$ : 表層透気係数 $\left(\mathrm{m}^{2}\right), V_{c}$ : 内部チャンバー の容積 $\left(\mathrm{m}^{3}\right)(=0.000165), A$ : 内部チャンバーの面積 $\left(\mathrm{m}^{2}\right)$ $(=0.001963), \mu$ : 空気の粘性係数 $\left(\mathrm{N} \cdot \mathrm{s} / \mathrm{m}^{2}\right)\left(20^{\circ} \mathrm{C}\right.$ で $2.0 \times$ $\left.10^{-5}\right), \varepsilon$ : コンクリートの空隙率の想定值 $\left(\mathrm{m}^{3} / \mathrm{m}^{3}\right), P_{a}$ : 大 気圧 $\left(\mathrm{N} / \mathrm{m}^{2}\right)(=1), \Delta P$ : 試験終了までの復圧量 $\left(\mathrm{N} / \mathrm{m}^{2}\right), t$ : 試験終了時間 $(\mathrm{s}), t_{0}$ : 試験開始時間 $(\mathrm{s})(=60)$

\section{（2）施エがかぶりコンクリートの品質に及ぼす影響}

かぶりコンクリートの品質変動に及ぼす施工上の要因 としては，打込み，締固め等の段階で発生する材料分離， すなわちコンクリートの構成材料割合の変化，および水 和程度を支配寸る養生に大別できる。 またこれらの影響 は, 打込久時点, すなわち運搬やポンプ圧送を経たコン クリートの品質によって異なる.

示方書 [施工編 : 施工標準 ${ }^{4}$ には，できる限り材料
分離を小さくし均質な構造体コンクリートを達成するた めの施工上の留意点が示されている. 例えば，打込み時 に適切なワーカビリティーを有したコンクリートを使用 するために，部材の種類，鉄筋量や鉄筋間隔，運搬や圧 送によるスランプロスなどを考慮した練上がり目標スラ ンプの設定方法が示されている. また，施工性能にもと づくコンクリートの配合設計・施工指針（案） ${ }^{10}$ で゙は, 適切な材料分離抵抗性および振動締固め性を得るために 必要なスランプと単位セメント量の組み合わせについて, 構造諸元等も考慮して提示されている. このような方法 に従って施工されれば，締固め間隔や締固め時間などの 施工要因が品質に大きな影響を及ぼさないことを，著者 $ら^{11)}$ も実験的に確認している. ただし, 従来から指摘さ れているように，締固め完了後のブリーディングの影響 によって高さ方向に品質変動が生じる場合があり, この ような変動をコンクリートの材料係数 $\left(\gamma_{c}\right)$ などとして, 適切に考慮する必要がある. 以上より, 本研究では, ブ リーディングが表層透気係数に及ぼす影響を検討対象と する.

本研究では, 中性化速度係数と表層透気係数との関係 を定式化し，ブリーディングが表層透気係数に及ぼす影 響を考慮することで，間接的にブリーディングが中性化 速度係数に及ぼす影響を定式化しており，この影響に関 しては, 3.(1)にて詳述する.

\section{3. 表層透気係数と種々の要因の整理}

\section{（1） 中性化速度係数と表層透気係数の関係}

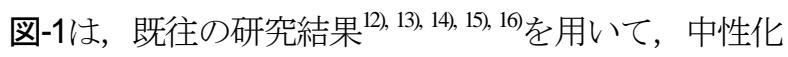
速度係数と表層透気係数の関係を示したものであり, 普 通ポルトランドセメントを用いたコンクリートを対象と して抽出した. 表-1は, 各文献における供試体の養生条 件, 表層透気係数の測定時期および中性化試験の方法お よび実施時期を整理したものである，中性化環境は屋内， 自然および促進があるため, 炭酸ガス濃度の換算が可能 な魚本・高田式17を用いて, 自然環境の炭酸ガス濃度 0.035\%に変換した後，ルート垻に基づき中性化速度係 数を求めた. 屋内の炭酸ガス濃度は文献No.Iには示され

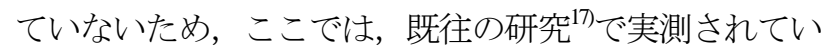
る0.07\%とした。 なお, 参考文献)では居室で計測した 結果が0.04 0.12\%と報告されており, 実験室内の実測結 果である $0.07 \%$ と概ね整合していると思われる.また， 文献No.IVの場合, 中性化深さの計測が複数あるため, 全てのデータを用いてルート垻に基づき中性化速度係 数を求めた. ここで, 文献No.I, II, IIIは主に水セメン 卜比の違いを, 文献No.IVは主に養生方法の違いを, 文 献No.Vは測定位置と表層透気係数の測定材齢の違いを 検討したものである. 


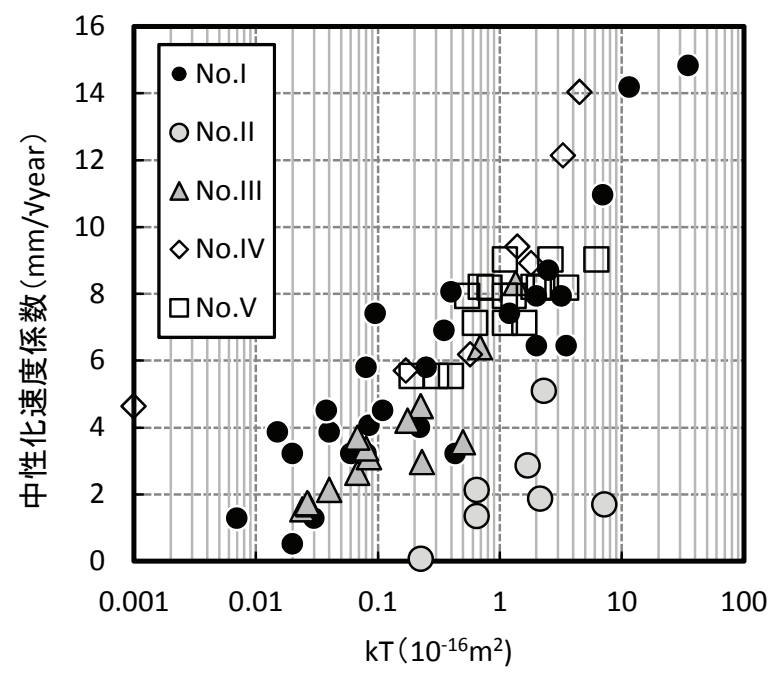

図-1 中性化速度係数と表層透気係数の関係

表-1 参照文献と条件の整理

\begin{tabular}{|c|c|c|c|c|}
\hline No. & 出典 & 養生条件 & 試験材齢 & $\begin{array}{c}\text { 中性化 } \\
\text { 試験条件 }\end{array}$ \\
\hline I & $\begin{array}{l}\text { RILEM } \\
\text { TC189 } \\
2007^{12)}\end{array}$ & $\begin{array}{c}7 \text { 日間 } 20^{\circ} \mathrm{C}, \\
95 \% \text { R.H. } \Rightarrow \\
20^{\circ} \mathrm{C}, \\
50 \% \text { R.H. }\end{array}$ & 28 日 & $\begin{array}{c}\text { Dry room } \\
\left(20^{\circ} \mathrm{C},\right. \\
50 \% \text { R.H. }) \\
500 \text { 日 }\end{array}$ \\
\hline II & $\begin{array}{c}\text { 小野・上 } \\
\text { 東 } \\
2005^{13)}\end{array}$ & $\begin{array}{c}2 \text { 日間湿潤 } \Rightarrow \\
\text { 約 } 1 \text { 年まで } \\
20^{\circ} \mathrm{C} 60 \% \text { R.H. } \\
\end{array}$ & 約 1 年 & $\begin{array}{l}\text { 約 } 1 \text { 年か } 5 \text { 自 } \\
\text { 然環境約 } 3 \text { 年 }\end{array}$ \\
\hline III & $\begin{array}{l}\text { 今本ら } \\
2009^{14}\end{array}$ & $\begin{array}{c}1 \text { ケ月間 } 20^{\circ} \mathrm{C} \\
\text { 水中 } \Rightarrow 1 \text { ケ月 } \\
\text { 間 } 20^{\circ} \mathrm{C}, \\
60 \% \text { R.H. }\end{array}$ & \begin{tabular}{|c|} 
2 月 (RILEM \\
法の透気係数 \\
と kT の関係か \\
ら推定)
\end{tabular} & $\begin{array}{c}\text { 雨掛かりのな } \\
\text { い自然環境 } \\
\text { 約 } 4 \text { 年 }\end{array}$ \\
\hline IV & $\begin{array}{l}\text { 白根ら } \\
2010^{15)}\end{array}$ & $\begin{array}{l}28 \text { 日間の養 } \\
\text { 生条件変化 } \\
\Rightarrow 60 \% \text { R.H. }\end{array}$ & 56 日 & \begin{tabular}{|c|}
$20^{\circ} \mathrm{C}, 60 \% \mathrm{R} . \mathrm{H}$ \\
$\mathrm{CO}_{2} 5 \%, 56$ 日 \\
で開始し促進 \\
$1,4,8$ 週 \\
\end{tabular} \\
\hline $\mathrm{V}$ & $\begin{array}{l}\text { 水上ら } \\
2011^{16)}\end{array}$ & $\begin{array}{c}5 \text { 日間封縅 } \Rightarrow \\
20^{\circ} \mathrm{C}, \\
60 \% \text { R.H. }\end{array}$ & $28 ， 56 ， 91$ 日 & \begin{tabular}{|c|}
$20^{\circ} \mathrm{C}, 60 \%$ R.H \\
$\mathrm{CO}_{2} 5 \%$, 91 日 \\
で開始し促進 \\
4週
\end{tabular} \\
\hline
\end{tabular}

困より，全体的な傾向としては，表層透気係数の増加 に伴い，中性化速度係数が大きくなっているが，異なる 実験条件で行われた両者の関係は，全体として同一の関 係にはない。これは，表層透気係数の測定時期や，中性 化進行における環境条件の違いが影響していると推察さ れる．表層透気係数は，コンクリートの空隙組織の緻密 さと含水状態の影響を受ける. そのため, 同一の材料・ 配合で製造され，同一の施工を施されたコンクリートで あっても，施工後の環境条件や材龃が異なれば，コンク リートの表層透気係数は経時的に変化する。図-1中の文 献No.Vは, 測定材齢の異なる表層透気係数の結果と, 材齢91日から促進中性化した結果を示しているが，同一 の中性化速度係数に対して，表層透気係数が変化してい
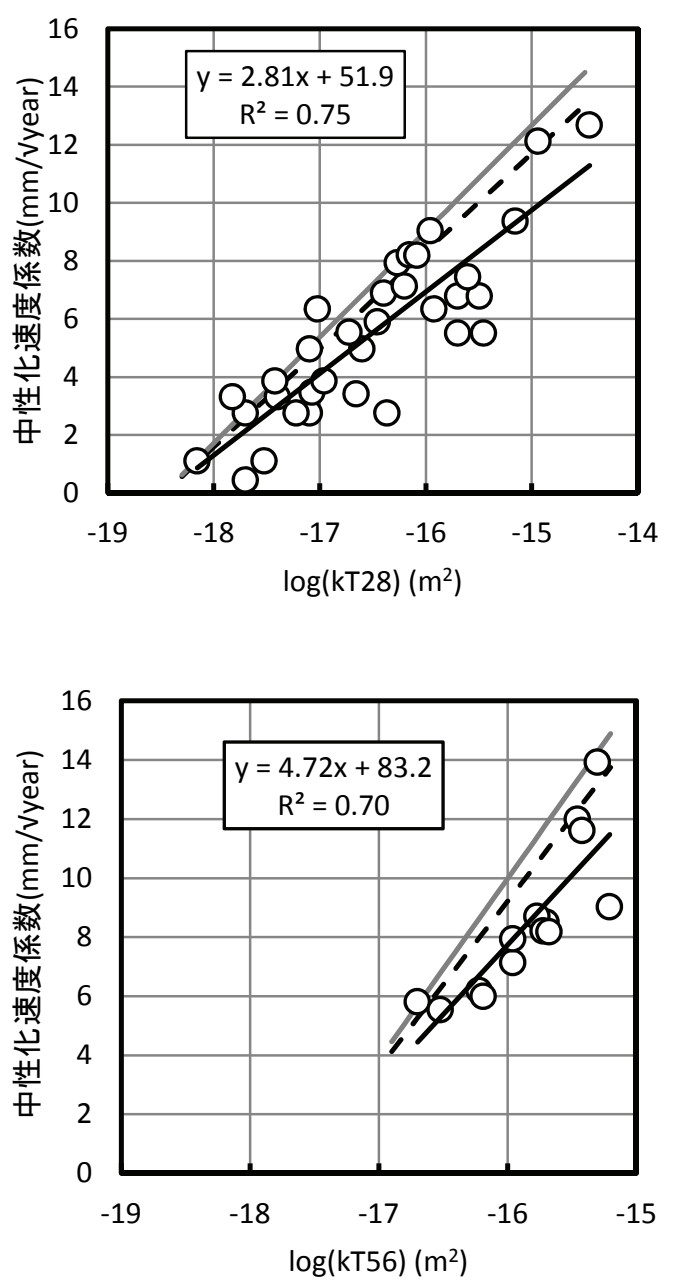

図-2 測定材齢毎の $k T$ と中性化速度係数の関係

ることがわかる.また，中性化の進行には環境作用，特 に水分の影響が大きく例えば19)，同一品質のコンクリート であっても，水分供給の有無によってコンクリートの中 性化進行は異なる．図-1は，表層透気係数の測定材齢が 異なるため単純な比較はできないが，水分供給を受ける 環境にある文献No.IIの中性化速度係数が小さいことから も，このような影響があることがわかる。

本研究は，施工後に達成されたコンクリートの品質を 表面透気試験で確認し，その結果をコンクリートの中性 化速度係数の特性值と関連づけることで, 設計一施工一 検査一維持管理の連係を試みるものである. そのため, 表層透気係数と関連づける中性化速度係数は，ある定め られた環境下で得られる結果とする必要があり，実際の 中性化進行の予測においては環境の影響を別途考慮する こととなる.

そこで，水分供給の影響のある文献No.II と，換算によ って表層透気係数を求めてるNo.IIIを除外し，測定材齢 28日（kT28）（文献No.I， No.V）および56日（kT56）

(文献No.IV, No.V) の結果と中性化速度係数の関係を 図-2に示す。なお，文献No.Iは50\%R.H.であるが，ルート 


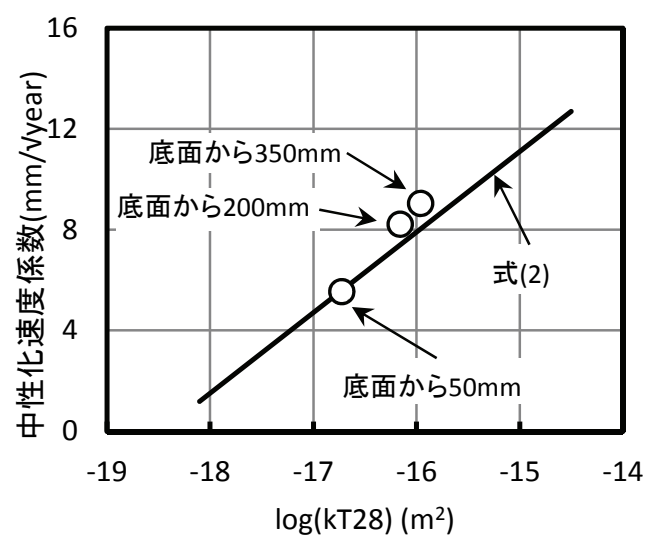

図-3 同一供試体における $k T 28$ と中性化速度係数の関係

則を適用した中性化深さの予測で湿度の影響を考慮し た既往の研究20)に基づき，60\%R.H.における中性化深さ に換算している，具体的には，50\%R.H.における中性化 深さの進行は，60\%R.H.に対して1.17倍であることを考 慮して換算している. 図より, 測定材齢毎に整理した表 層透気係数の常用対数と中性化速度係数 $(\alpha \mathrm{mm} / \sqrt{\text { year }})$ は概ね線形関係があり, 式(2)のように定式化できる.

$$
\alpha=a_{i} \log (k T i)+b_{i}
$$

ここに, $i$ : 表層透気係数の測定材齢, $a_{i}, b_{i}$ : 実験定 数 $\left(a_{28}=2.81, b_{28}=51.9, a_{56}=4.72, b_{56}=83.2\right)$

なお，これらの近似直線は実測值の平均的な関係を示 している，図中には，式(2)の結果（図中黒色実線）, 予測結果を1.2倍（図中点線）および1.3倍（図中灰色実 線）した結果も合わせて記載している.

測定材齢28日のデータが多く収集できたため，本研究 では，この結果に基づいて得られた関係を4.で用いるこ ととする．なお，本研究では測定材齢28日を用いている が，以降で求める種々の関係について，28日以外の材齢 で定式化されれば，その材齢の結果を用いることも可能 であると考えられる。

本研究では，ある定められた環境下における表層透気 係数と中性化速度係数の関係を定式化し（式(2)），ブ リーディングが表層透気係数に及ぼす影響を考慮するこ とで (3.(2)，3.(3)），間接的にブリーディングが中性化 速度係数に及ぼす影響を定式化する．これは，ブリーデ イングが表層透気係数に及ぼす影響と，ブリーディング が中性化速度係数に及ぼす影響が同様であることを前提 としていることとなる. 表層透気係数は気体の移動のし 易さを示寸指標であるのに対して，中性化速度係数は炭 酸ガスの移動と水和生成物との反応によって定まる特性 值である．そのため中性化における反応の影響によって は，ブリーディングが表層透気係数に及ぼす影響と，ブ リーディングが中性化速度係数に及ぼす影響が異なる可

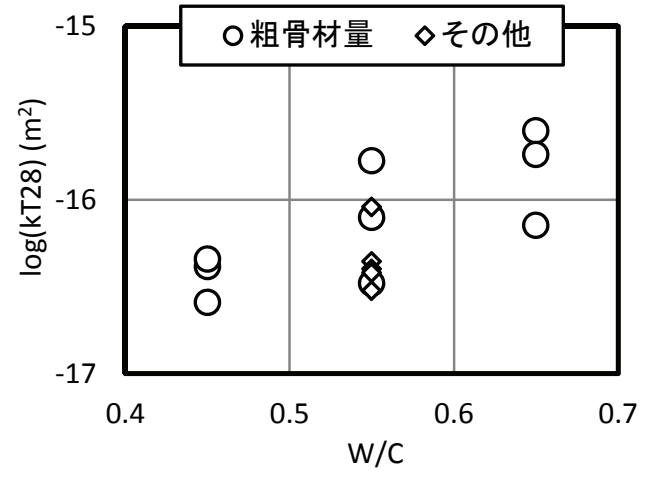

図-4 水セメント比と表層透気係数の関係

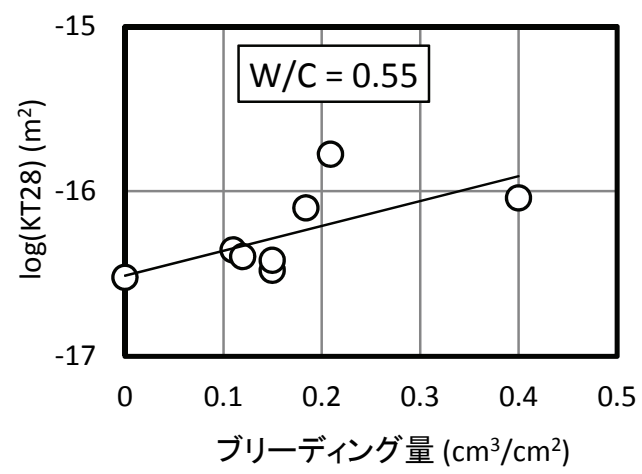

図-5 ブリーディング量と表層透気係数の関係

能性がある、ここで，ブリーディングの影響を確認する ためには，同一供試体内の異なる高さにおける表層透気 係数と中性化速度係数の関係を検討寸る必要があり, 文 献No.Vで該当する結果のみを取り出し図-3に示寸. 図よ り表層透気係数と中性化速度係数の関係は概ね式(2)で 示される関係にあり, ブリーディングが表層透気係数あ るいは中性化速度係数に及ぼす影響が同様であると考え られる，ただし，検討は1ケースのみであるため，今後 も継続的に検討寸る必要があるが，本研究では，ブリー ディングが表層透気係数に及ぼす影響と，ブリーディン グが中性化速度係数に及ぼす影響が同様であるとする.

\section{（2）表層透気係数の予測}

図-4は，3種類の水セメント比 $(0.45,0.55,0.65)$ に ついて粗骨材量を変化させた場合, および水セメント比 を0.55一定として, 単位水量あるいは細骨材種類を変化 させた場合や増粘剤を混入した場合の，水セメント比と 表層透気係数の関係である゙．材龄5日まで封縅養生し, その後, 室内に静置している. 図より, 同一水セメント 比でも表層透気係数が異なっていることがわかる.

図-5は，図-4に示した水セメント比0.55のときの，ブ リーディング量と表層透気係数の関係であり, 一定の相 関が認められる. 図中の実線は直線回帰の結果である. なお, 既往の研究においても, 単位水量の大小によるブ リーディングの発生のし易さが，表層透気係数に影響を 


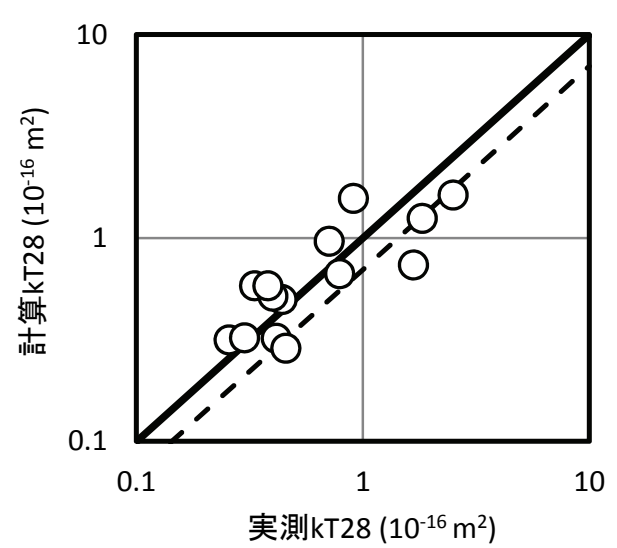

図-6 実測值 $k T 28$ と予測值 $k T 28$ の関係

及ぼすことが指摘されている22, 21). コンクリート上面に 到達寸るブリーディング水は，型枠面との境界を上昇す る水と, コンクリート内部から上昇する水の総和である と考えられ22)，水の上昇に伴って水みちが形成される. また，コンクリート上面に達寸ることなくコンクリート 内部に留まる水は22), 硬化コンクリート中の空隙になる 可能性がある. ブリーディングによって生じた水みちや 空隙が，コンクリートの物質透過性に及ぼす影響は必ず しも定量的に明らかとされていないが，水みちや空隙の 増加に伴いコンクリートの物質透過性も増加寸る傾向を 示すと考えられる. このように，ブリーディングの影響 により，同一水セメント比のコンクリートにおいても表 層透気性は異なる可能性があり，本研究では，表層透気 係数を水セメント比（W/C）およびブリーディング量 $\left(B \mathrm{~cm} / \mathrm{cm}^{2}\right)$ の関数として表現する.

式(3)は，著者らの実験結果 ${ }^{3)}$ 用いて重回帰分析を行 った結果である. 決定係数は0.66であり，式(3)を用いて 計算した結果（図-6参照）は，実測值の70\%を概ね上回 る (図-6中の点線) 。そのため，水セメント比とブリー ディング量から式(3)を用いて予測した結果を1.43（=1/0.7） 倍することで，概ね安全側の評価が可能であると考えら れる.

$$
\log (k T 28)=A \times \frac{W}{C}+B \times B l+C
$$

ここに, $A, B, C$ : 実験定数 $(A=1.88, B=1.71, C=$ 一 $17.5)$

\section{(3) 材料分離が表層透気係数に及ぼす影響}

ここでは，同一構造物内の高さ方向の表層透気係数の 変動に関して検討するが，示方書 [施工編 : 施工標準 $]$ には，コンクリート打込みの1層の高さは，使用する内 部振動機の性能などを考慮して40〜50cm以下を標準と している. そのため，これ以上の高さの構造物を建造す る場合には打重㸚る必要があり，高さ方向の表層透気係
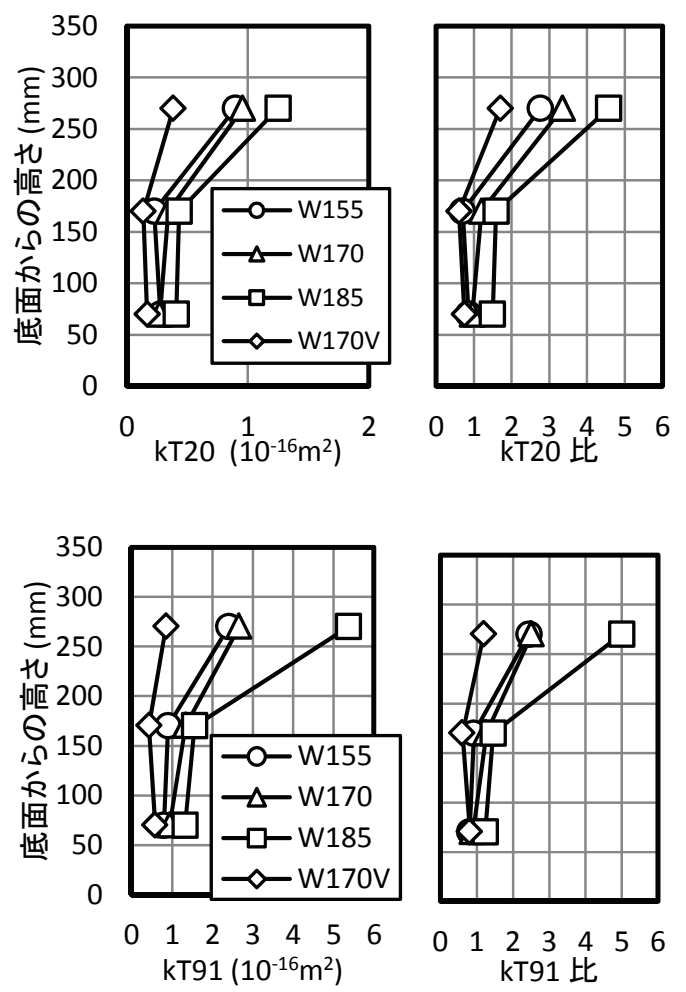

図-7＼cjkstart表層透気係数の高さ方向の変化

数の変動の検討においても，打重ねの影響を考慮する必 要がある.

図-7は，高さ350mm，鉄筋のあきが35mmの供試体の 表層透気係数の計測結果であり, 水セメント比 0.55 , 単 位水量 $155,170,185 \mathrm{~kg} / \mathrm{m}^{3}$ と単位水量 $170 \mathrm{~kg} / \mathrm{m}^{3}$ の配合に増 粘剤を混入しブリーディングの発生を抑制した場合の合 計4種類の結果である ${ }^{11,23)}$. 材齢5日まで $20^{\circ} \mathrm{C}$ 封緘養生し, その後 $20^{\circ} \mathrm{C} ， 60 \%$ R.H.の室内に置き，材齢20日および 91 日の測定結果である. 各測定点の縦軸の值は，底面から チャンバーの中心までの高さ（以下，測定中心高さ）

（70mm，170mm，270mm）を用いた. kT20比およびkT91 比は，各高さの測定結果を基準供試体（1辺150mmの立 方体）の同一測定材齢における表層透気係数で除した値 である（以下，表層透気係数比）。なお，基準供試体の 測定材齢28日の結果は式(3)の導出に用いている．何れの 測定材齢も，単位水量 $185 \mathrm{~kg} / \mathrm{m}^{3}$ をのぞき，中・下層のコ ンクリートの表層透気係数は，基準供試体と同等以下で あることがわかる，上層のコンクリートでは，何れの場 合も基準供試体の表層透気係数を大きく上回っており， 材料分離に伴うブリーディング水の影響によるものと考 えられる。ここで，測定材齢の影響を検討するため，図 -8に測定材齢20日と91日の表層透気係数比の関係を示す. 図より，測定材齢によって表層透気係数比が多少異なる ものの，基準供試体に対する高さ方向の表層透気係数の 変動は，測定材齢に依らず概ね一定の関係を示している.

図-9は，水セメント比 0.55 ，単位水量 $170 \mathrm{~kg} / \mathrm{m}^{3}$, 断面 


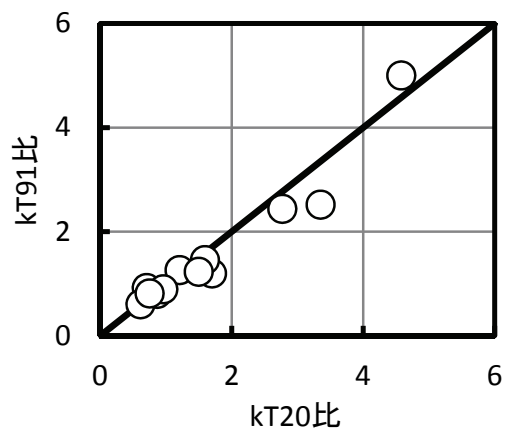

図-8 $k T 20$ 比と $k T 91$ 比の関係

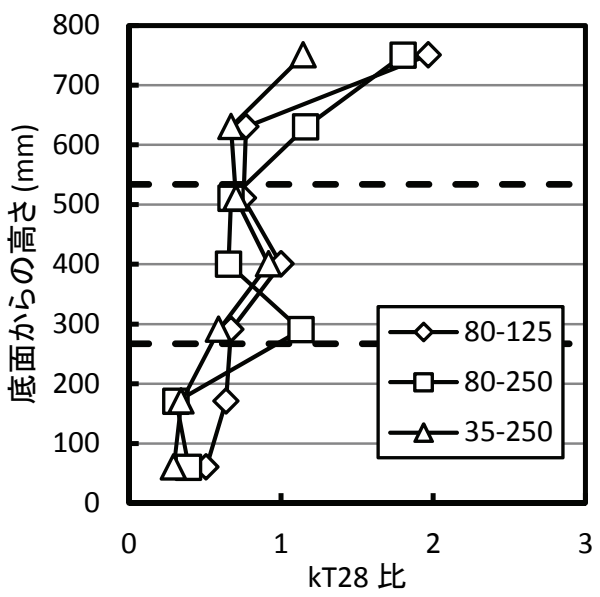

図-9 表層透気係数比の高さ方向の変化

$500 \times 500 \mathrm{~mm}$ ，高さ $800 \mathrm{~mm} ， 1$ 層約 $270 \mathrm{~mm}$ の3層で作製し た供試体の表層透気係数の結果である23)，打設面をシー トで覆い材齢5日まで $20^{\circ} \mathrm{C}$ 室内で養生し，脱型後は温 度制御されていない室内で保管している，なお，各測定 点の縦軸の值は図-7と同様に測定中心高さ（60mm,

170mm, 290mm, 400mm, 510mm, 630mm, 750mm) を, 横軸は測定材齢28日の表層透気係数比を示している. 凡 例は鉛直方向の鉄筋のあきと水平方向の鉄筋のあきを意 味しており，図中の点線は打重亦位置を示している。底 面から1層目および2層目の表層透気係数は，そのほとん どが基準供試体よりも小さい值を示している。これは， 上層コンクリートの圧密の影響によるものと考えられ， 底面に近いほど，より小さな数值を示す傾向にある. 図 -9に示した結果では，基準供試体に対して1層目が平均 で 0.5 程度，2層目が平均で 0.8 程度となった。 1層打ちの 結果（図-7）では，底面から測定中心までの高さが 270mmにおける表層透気係数が非常に大きくなったのに 対し, 打重ねた場合の最上層以外のコンクリートには, このような現象は確認できず，圧密の影響の無い最上層 のコンクリートのみ，1層打ちとほぼ同様な傾向を示し ている．また，今回の範囲内では，鉛直および水平方向 の鉄筋のあきは，表層透気係数の高さ方向の変動には， それほど大きな影響を及ぼさない結果となっている.

高さ方向の表層透気係数の変動は，コンクリート自体

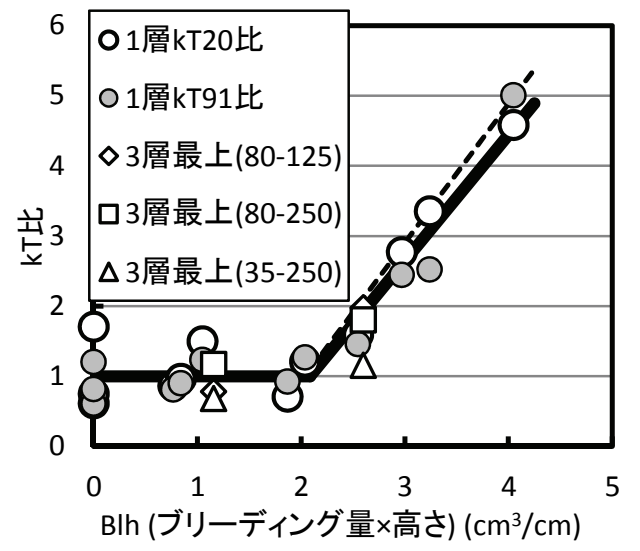

図-10 ブリーディング指標と表層透気係数比の関係

のブリーディング性状と, 締固め後のブリーディングの 駆動力, すなわち打込み高さによって異なる自重の大き さに支配されると考えられる，そこで，コンクリートの ブリーディング試験結果に表面透気試験における底面か ら測定中心までの高さを乗じたもの（以下，ブリーディ ング指標：Blh）を指標として，表層透気係数比との関 係を整理した結果を図-10に示す，なお，打重ねの場合 は，底面からの高さではなく最上層のみの高さとして考 慮し，1層および2層は圧密の影響で基準供試体よりも小 さな数值を示しているため除外した．打重ねの場合の表 層透気係数の測定材齢は28日，凡例の1層は図-7の結果 であり，測定材齢20日と91日である。図より，ブリーデ イング指標が 2 付近までは，基準供試体とほぼ等しい表 層透気係数を示すが, その後, 直線的に増加している. この関係を定式化すると，式(4)のようになる，なお， 本研究の範囲では検討数が少ないため今後も継続した検 討が必要であるが，本研究では，表層透気係数比の高さ 方向の変動は，表層透気係数の測定材齢91日までは測定 材齢に依らず式(4)により求まることとする.

$$
\begin{aligned}
\frac{k T i}{k T i_{s}} & =1.0(B l h \leq I) \\
\frac{k T i}{k T i_{s}} & =I I \times B l h+I I I \quad(I<B l h)
\end{aligned}
$$

ここに, $k T i_{\mathrm{s}}$ : 基準供試体の測定材齢 $i$ における表層透

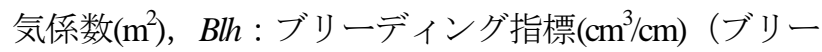
ディング量 $0.2 \mathrm{~cm}^{3} / \mathrm{cm}^{2}$ 程度，高さ $35 \mathrm{~cm}$ で検討），I，II, $I I I$ : 実験定数 $(I=2.09, I I=1.80, I I I=-2.76)$

図中の点線は，式(4)で得られる透気係数比を1.1倍し たものであるが，高さ方向の変動に関しては，ブリーデ イング量と高さから式(4)を用いて予測した結果を1.1倍 することで，概ね安全側の評価が可能である.

ここで，1層の打込み高さが35cm（底面から測定中心

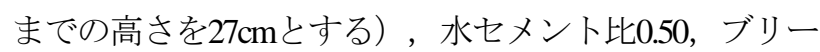
ディング量 $0.10 \mathrm{~cm}^{3} / \mathrm{cm}^{2}$ を例に試算してみる．測定中心高 
さとブリーディング量からブリーディング指標を求め, これを式(4)に代入することで，測定中心高さにおける 表層透気係数は基準供試体の2.1倍（安全側 : 2.3倍）と 求まる. 水セメント比とブリーディング量を式(3)に代 入し, 高さ方向の変動が無い, 寸なわち基集供試体の測 定材齢28日の表層透気係数 $\left(0.41 \times 10^{-16} \mathrm{~m}^{2}\right)$ を得る. 求 めた值を2.1倍することで，測定中心高さにおける測定 材齢28日の表層透気係数 $0.86 \times 10^{-16} \mathrm{~m}^{2}$ （安全側の評価で あれば2.3倍することで $\left.0.94 \times 10^{-16} \mathrm{~m}^{2}\right)$ が求まる. 求めた 表層透気係数を式(2)に代入することで中性化速度係数 が得られる. この場合, 測定中心高さ27cmにおける中 性化速度係数は, 高さ方向の変動がない基準供試体の中 性化速度係数に対して1.15倍（安全側：1.17倍）となる.

\section{（4）本研究で考慮していない要因の整理}

式(2), 式(3), 式(4)で用いた著者らの既往の成果は, 普通コンクリートを，1層の打込文高さが $35 \mathrm{~cm}$ 以内で内 部振動機を用いて締固め, 封緘養生した, 品質管理が容 易な試験室で実施した結果が基本となっている，そのた め, 使用材料, 配合, 運搬, 締固め方法, 打重ね, 養生 などの影響や，供試体と実構造物の差異などの影響を今 後も検討する必要がある，例えば，昨今，養生の重要性 が再認識され，多くの検討が実施されている例えは24, 25). 本研究で対象とした主な養生条件は封縅養生であり, 水 中養生に近い養生や透水性型枠などを用いた養生の場合 では，同配合の同材齢におけるコンクリートの表層透気 係数は, 本研究で対象としたコンクリートよりも小さな 值を示寸と考えられる. 式(2)の定式化に用いた文献No.I の養生条件も封縅養生とは異なるため, 今後, 式(2)〜 式(4)の定式化において, 養生の効果を説明変数として 考慮していく必要がある.また，セメント種類が異なれ ば，式(2)や式(3)の関係に影響を及ぼすと考えられ，そ の影響も検討していく必要がある.

以上のように本研究の成果は限定された範囲での結果 に基づいており，今後も継続した検討が必要であるが， 次章では, これらの式を用いて表面透気試験を用いた設 計と検査の連係の考え方を示す. なお，本研究で用いた 表面透気試験では，表層透気係数が $1.0 \times 10^{-16} \mathrm{~m}^{2}$ 程度の場 合，表面から深さ30～40mm程度のコンクリートの平均 的な透気係数が測定される ${ }^{23)}$. そのため，かぶりが 40mmを大きく超えるような場合では, 計測される表層 透気係数が，かぶりの平均的な品質を表現していない可 能性がある. 一般的には表層部より内部のコンクリート 品質が高いため, 表層透気係数によってかぶりの平均的 な品質を表現した場合は, 安全側の評価になると考えら れる. 以上のことから，かぶりが大きい場合の評価方法 は, 今後も検討する必要があるが，本研究では，安全側 の評価が可能であると考えられることから，表層透気係
数がかぶりコンクリートの平均的な品質を表現するとし て検討を進める.

\section{4. 表面透気試験を用いた設計と検査の連係の考 え方について}

\section{（1）表層透気係数を用いた設計の考え方}

本研究では, 材料・配合および施工要因が実構造物で 達成されるコンクリートの品質（ここでは，中性化速度 係数）に及ぼす影響を, 表層透気係数によって評価可能 であることを前提とし，表面透気試験を実構造物の検査 に用いることを想定している. また, 品質が同じコンク リート構造物の中性化の進行は, 構造物が置かれた環境 条件によって異なるが，この影響は，検査の合否判定の 基準值として用いる表層透気係数には含まず，中性化深 さの予測において考慮する．このような考え方に基づき， コンクリートの中性化速度係数の設計值の設定を式(5) により行う（以下，本手法）。

$$
\begin{aligned}
& \alpha_{d}=\alpha_{k} \cdot \beta_{e} \cdot \gamma_{c} \\
& \alpha_{k} \geq \gamma_{p \alpha} \cdot \alpha_{p} \\
& \alpha_{p}=f(k T 28) \\
& k T 28=f(W / C, B l) \cdot \beta_{c 1} \cdot \gamma_{p k T} \cdot \gamma_{p b l} \cdot \gamma_{c k T} \cdot \gamma_{c c}
\end{aligned}
$$

ここに， $\alpha_{d}$ : 中性化速度係数の設計値 $(\mathrm{mm} / \sqrt{\text { year }})$, $\alpha_{\mathrm{k}}$ : 中性化速度係数の特性值 $(\mathrm{mm} / \sqrt{\text { year }}), \beta_{\mathrm{e}}$ : 環境作 用の程度を表す係数, $\gamma_{c}$ : コンクリートの材料係数, $\gamma_{p \alpha}$ : 式(2)の精度に関する安全係数, $\alpha_{p}$ : 中性化速度係数 の予測值 $(\mathrm{mm} / \sqrt{\text { year }}), \beta_{\mathrm{cl}}\left(=k T i / k T i_{s}\right)$ : 高さ方向の変動 を表す係数, $\gamma_{p k T}$ : 式(3)の精度に関する安全係数, $\gamma_{p b l}$ : 式(4)の精度に関する安全係数, $\gamma_{\alpha T}$ : 基準供試体および 表面透気試験のばらつきに関する安全係数， $\gamma_{c}$ : 供試体 と実構造物の差に関する安全係数

本研究の検討範囲は限定的であるが，中性化に伴う鋼 材腐食において, 表面透気試験を用いた設計と検査の連 係の考え方を示寸上では，具体的な例を用いて現行の設 計体系と比較することが有意義であると思われる．ただ し, 用いている具体的な数值は, あくまでも考え方を理 解しやすくするための手段であり, 数值そのものが信頼 性の高い結果を提示しているわけではないことに注意さ れたい.

表-2に示方書 [設計編 : 本編] の中性化の照査および 材料の設計值（中性化速度係数）をまとめたものと，検 查にて表面透気試験を用いることを前提とした本手法と の対応を示寸。

環境作用の程度を表寸係数 $\left(\beta_{e}\right)$ は, 示方書では屋外 暴露の結果に基づいて有効水結合材比と中性化速度係数 
表-2 示方書と提案手法の対比

\begin{tabular}{|c|c|c|}
\hline 項目 & 示方書 & 本手法 \\
\hline$\alpha_{d}$ & $\alpha_{k} \cdot \beta_{e} \cdot \gamma_{c}$ & $\alpha_{k} \cdot \beta_{e} \cdot \gamma_{c}$ \\
\hline$\alpha_{k}$ & $\gamma_{p} \cdot \alpha_{p}$ & $\gamma_{p \alpha} \cdot \alpha_{p}$ \\
\hline$\alpha_{p}$ & $f(W / B)$ & $f(k T 28)$ \\
\hline$k T 28$ & - & $f(W / C, B l) \cdot \beta_{c 1} \cdot \gamma_{p k T} \cdot \gamma_{p b l} \cdot \gamma_{c k T} \cdot \gamma_{c c}$ \\
\hline
\end{tabular}

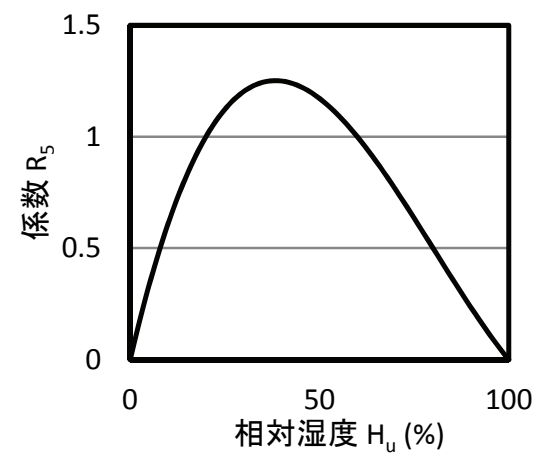

$$
R_{5}=H_{u}\left(100-H_{u}\right)\left(140-H_{u}\right) / 192000
$$

図-11 中性化深さの進行予測における湿度の影響

の関係が求められているため, 乾燥しやすい環境では 1.6を，乾燥しにくい環境では1.0としている。 これに対 し，図-2および式(2)で示したように，本研究では，既往 の研究に基づき $60 \%$ R.H.における中性化速度係数の結果 を用いている。ここで，既往の研究20)を参考にすると

（図-11参照），中性化の進行に及ぼす相対湿度の影響 は，60\%および20\%で1.0，40\%で最大值1.25を示す関数と なっており, 本研究における環境作用の程度を表寸係数

$\left(\beta_{e}\right)$ も, 図-11中のRs と同様の関数として与えること が可能であると考えられるが，詳細な影響については今 後の課題とし, 本論文での取り扱いについては, 4.(3)に て説明する.

示方書のコンクリートの材料係数（ $\gamma_{c}$ ) は, 実構造物 における材料分離の影響や標準養生供試体との品質の差 を考慮した安全係数であると考えられ，その影響は中性 化速度係数の設計值の設定において考慮されている. 本 研究では，これらの影響を高さ方向の変動を表す係数

$\left(\beta_{c 1}\right)$ ，供試体と実構造物の差に関寸る安全係数（ $\left.\gamma_{c c}\right)$ として考慮し, 表層透気係数の設定において考慮するこ ととしている. なお，本研究の結果は試験室の結果に基 ゔいているため, 現時点では供試体と実構造物の差に関 寸る安全係数 $\left(\gamma_{c c}\right)$ の具体的数值はわからないため, 4.(3)では1.0とする.

示方書におけるコンクリートの材料係数が包含する影 響の解採が正しければ，本手法における中性化速度係数 の設計值の設定においてコンクリートの材料係数を考慮 する必要は無いと考えられ，4.(3)ではコンクリートの材 料係数 $\left(\gamma_{c}\right)$ を1.0としている.

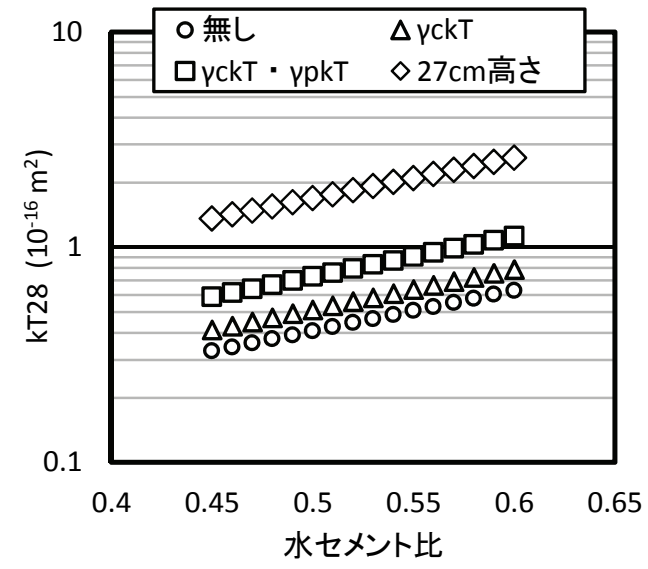

図-12 水セメント比と $k T 28$ の関係 $\left(B l=0.10 \mathrm{~cm}^{3} / \mathrm{cm}^{2}\right)$

中性化速度係数の特性值と中性化速度係数の予測值と の関係は，示方書と同様とするが，中性化速度係数の予 測值の精度に関する安全係数は，式(2)の精度に関する 安全係数 $\left(\gamma_{p a}\right)$ としている.

中性化速度係数の予測值は, 表層透気係数から式(2) を用いて予測する.

圧縮強度等の試験結果で見られるのと同じく, 表面透 気試験結果も同一バッチのコンクリートから供試体を作 製しても，測定結果は等しくない。このばらつきには， コンクリート自体のばらつきと測定方法のばらつきが含 まれており，式(5)および表-2では $\gamma_{\alpha T}$ として考慮してい る. 本研究で基準として用いた供試体の測定結果の変動 係数は配合によって若干異なるが，平均的な変動係数は 20\%程度であった．示方書の圧縮強度と同様に正規分布 を仮定して95\%確率で安全係数を求めると1.45となり, $1 \sigma$ 内を許容範囲と寸れば安全係数は 1.25 となる. コンク リートの中性化速度係数のばらつきを考慮した安全係数 の設定方法について，示方書には圧縮強度のような明確 な記述が無いため, 妥当な取扱い方法ついては今後も議 論が必要であると思われるが，ここでは1.25を採用する.

\section{（2）パラメトリックスタディ}

本手法では, 中性化速度係数と表層透気係数を, 水セ メント比 $(W / C)$ ，ブリーディング量 $(B l)$, 高さ（材 料分離による基準供試体に対する変動 $\beta_{\mathrm{cl}}$ ) ， ばらつき および精度に関する安全係数 $\gamma_{\alpha k}, \gamma_{p o s}, \gamma_{p k T}, \quad \gamma_{p b l}$ に基づき 定式化している．ここでは，これらの值の変化が表層透 気係数あるいは中性化速度係数に及ぼす影響をパラメト リックスタディにより検討する.

図-12は，水セメント比と表層透気係数の関係を示し たものであり, ブリーディング量を $0.1 \mathrm{~cm}^{3} / \mathrm{cm}^{2}$ 一定とし たときの, 安全係数の影響および高さの影響を算定した 結果である. 1層の打込み高さを $35 \mathrm{~cm}$ （測定中心高さを 27cm）としている. なお, 通常水セメント比が変化す れば，ブリーディング量も当然変化するが，ここでは一 


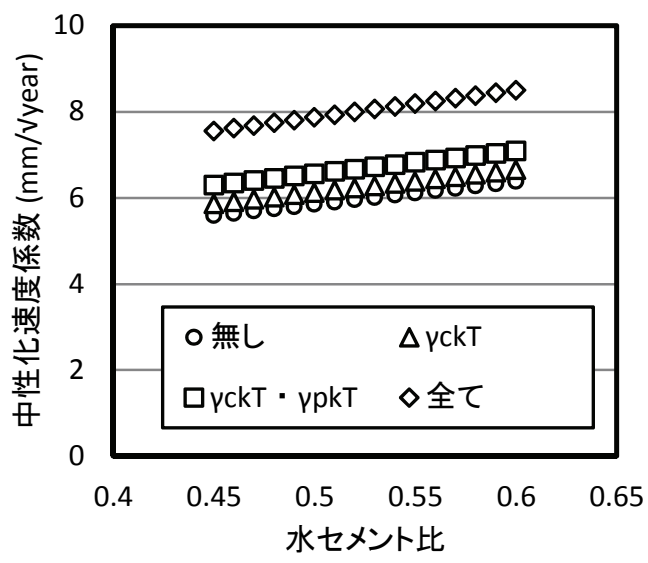

図-13 水セメント比と中性化速度係数の関係 $\left(B l=0.10 \mathrm{~cm}^{3} / \mathrm{cm}^{2}\right)$

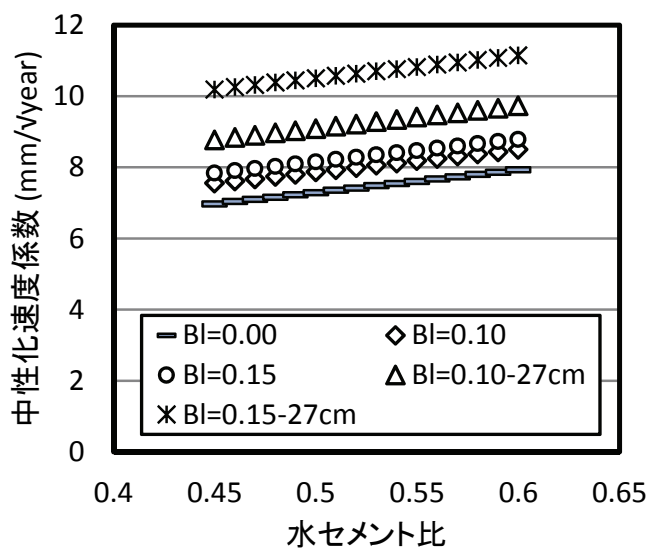

図-14 水セメント比と中性化速度係数の関係

定として算定しているため，仮想的な状況であることに 注意されたい，表層透気係数の予測に係わるばらつきお よび精度に関する安全係数は, 単純な積として考慮して いるため，安全係数を考慮していない結果（図中○）の， 1.25倍（図中 $\triangle ） お よ ひ ゙ 1.25 \times 1.43=1.79$ 倍（図中 $\square ）$ とな っている．測定中心高さ $27 \mathrm{~cm}$ （図中27cm高さ）では, 安全係数1.79倍に，ブリーディング指標を式(4)に代入し て得られる変動比率2.1倍と $\gamma_{\text {bl }}=1.1$ 倍を乗じて, 4.13倍 (図中 $\diamond)$ となっている.

図-13は，安全係数の考慮の有無が，水セメント比と 中性化速度係数に及ぼす影響を示しており，図-12の測 定中心高さ27cm以外の算定結果を中性化速度係数に変 換した場合にくわえて, 式(2)の精度に関する安全係数

$\left(\gamma_{p \alpha}\right)$ を図-2の一点破線で示した1.2とした場合（図中 ৩全て）の結果である．先ほどの表層透気係数の結果で, 1.25倍，1.79倍であった安全係数の影響は，中性化速度 係数に対しては，おおよそ1.05倍，1.12倍となっている.

図-14は，全ての安全係数を考慮した場合のブリーデ イング量の変化 $\left(0.00,0.10,0.15 \mathrm{~cm}^{3} / \mathrm{cm}^{2}\right)$ が, 水セメン 卜比と中性化速度係数に及ぼす影響を示している. 一般 的には，低水セメント比ほどブリーディング量が少なく なるため, 実際の水セメント比と中性化速度係数の関係
表-3 設計条件

\begin{tabular}{|c|c|c|}
\hline \multicolumn{2}{|c|}{ 中性化に対する耐用年数 year } & 50 \\
\hline \multicolumn{2}{|c|}{ かぶりの設計值 mm } & 70 \\
\hline \multicolumn{2}{|c|}{ 中性化残り $\mathrm{mm}$} & 10 \\
\hline \multicolumn{2}{|c|}{ 中性化深さの設計值 mm } & $\leqq 60$ \\
\hline \multicolumn{2}{|c|}{$\begin{array}{l}\text { 中性化深さの設計值のばらつきを考慮 } \\
\text { した安全係数 } \gamma_{b}\end{array}$} & 1.15 \\
\hline \multicolumn{2}{|c|}{ 中性化速度係数の設計值 $\alpha_{d} \mathrm{~mm} / \sqrt{\text { year }}$} & $\leqq 7.38$ \\
\hline \multirow{2}{*}{ 環境（東京） } & 平均相対湿度\% & 60 \\
\hline & 降水日数 day & 133 \\
\hline
\end{tabular}

環境条件は気象庁提供データの2001〜2010年の平均值

は，低水セメント比でブリーディング量が少ない結果と 高水セメント比でブリーディング量が多い結果を結んだ ものになると考えられる. また, 図中には測定中心高さ 27cmの算定結果（図中0.10-27cm，0.15-27cm）も示してい るが, ブリーディング量が0の場合は，式(4)においてブ リーディング指標が 0 となるため高さ方向の変動は無く, $27 \mathrm{~cm}$ 高さにおいても図中のBl $=0.00 \mathrm{~cm}^{3} / \mathrm{cm}^{2} の$ 算定結果と 等しくなる.

\section{(3) 適用例}

\section{a) 本手法に基づく設計例}

本研究の結果を用いた場合の，中性化の照査における 設計の流れを示す.

表-3は想定した設計条件を示している. 上層コンクリ 一トの圧密の影響を受けない最上層を対象として，この 設計条件を満足する水セメント比とブリーディング量を, 1層の打設高さが $35 \mathrm{~cm}$ （測定中心高さ27cm）の場合につ いて試算する.

中性化速度係数の設計值と特性值の関係には，環境の 影響とコンクリートの材料係数を考慮する必要がある.

環境の影響については，図-11に基づき降水期間は中 性化は進行しないと仮定すると, 表-3に示した降水日数 より，1年間に中性化が進行する期間は（365日－133日） $/ 365$ 日 $=0.64$ となる。.また，降水期間以外の相対湿度の 変化が中性化の進行に影響すると考えられるが，ここで は, 降水期間以外の相対湿度は, 平均相対湿度 (60\%R.H.) と仮定した. 厳密には, 降水日数としてカ ウントされている日内においても降水の有る時間带と無 い時間帯があることや，平均の相対湿度は降水期間も含 んだものであることから，害際の中性化の進行と本研究 の仮定は異なると考えられる．前記したように，環境作 用が中性化の進行に及ぼす影響については，今後の検討 課題とし, 本研究では簡易な仮定に基づき適用例を試算 することとした，以上の仮定に基づくと，式(2)を求め た実験結果の相対湿度が60\%であるため, 中性化が進行 する期間の平方根が環境作用の程度を表す係数となり， 今回の場合は $\beta_{e}=0.8$ となる. 
コンクリートの材料係数については，4.(1)に記したよ うに 1.0 とする.

これらの条件と設定した安全係数，および設計条件を 満た寸表層透気係数を表-4に示寸.

表-3の中性化速度係数の設計值と, 環境作用の程度を 示寸係数およびコンクリートの材料係数から, 中性化速 度の特性值を求める.

続いて，表層透気係数から中性化速度係数を予測する 式(2)の精度に関する安全係数を考慮して, 中性化速度 係数の予測值を定める.

式(2)を用いて，中性化速度係数の予測值に対応寸る 表層透気係数を求める.この数值は，実構造物の計測結 果がこの条件を満たしていれば，設計条件を満足するこ とを示しており，この数值を検査の合否判定の基準值 (以下，kT28I) と考えることもできる.

さらに, 式(3)の精度に関する安全係数およびばらつ きに関する安全係数を考慮して, 高さ方向の変動が無い 場合の表層透気係数 $\left(k T 28_{\mathrm{s}}\right)$ が定まる.この条件を満 足するように, ブリーディング量を考慮して水セメント 比を選定するが，最上層の上部では式(4)と式(4)の精度 に関する安全係数を用いて目標とする表層透気係数 $\left(k T 28_{\text {up }}\right)$ を求め, これを満足する水セメント比を選定 することとなる.

計算結果を図-15に示す，図中には，最上層の上部 (測定中心高さ27cm) の場合（図中，kT28 4 up ) 高さ 方向の変動を無視した場合 (図中, $k T 28_{5}$ ) を示してい る. 図から, ブリーディング量の増加に伴い, 条件を満 足寸る水セメント比は低下していくことがわかる．なお， 今回の測定中心高さ $27 \mathrm{~cm}$ では，ブリーディング量が $0.077 \mathrm{~cm}^{3} / \mathrm{cm}^{2}$ 以下であれば，式(4)より高さ方向の品質変 動は無いため, $k T 28_{u p}$ と $k T 28_{5}$ の結果が等しくなっている. 条件を満足するブリーディング量と水セメント比との組 み合わせは, $k T 28_{u p}$ の計算結果の内側となり, 例えば, ブリーディング量が $0.1 \mathrm{~cm}^{3} / \mathrm{cm}^{2}$ であれば, 水セメント比 が0.52未満となる配合であればよいこととなる.

\section{b）本手法に基づく検査の考え方と初期性能の把握}

本研究では，材料分離が構造体かぶりコンクリートに 及ぼす影響を考慮すべく, ブリーディング量を指標とし て採用している.ブリーディング試験はJIS A 1123に基 づき実施しているが，この場合，ブリーディング水の上 昇がなくなるまで計測する必要があり, 少なくとも3時 間程度は必要となる。 そのため, 本試験をコンクリート の受け入れ検査として採用寸ることは現実的ではないが, 施工記録として残しておくことは，製造プラントでの品 質管理，翌日以降の配合修正や不具合発生時の原因究明 などのために有意義であると考えられる.

また, 構造体かぶりコンクリートの検査は材齢28日を 前提として具体例を用いて説明したが，式(2)〜式(4)で
表-4 安全係数等の条件と設計条件を満足する表層透気係数

\begin{tabular}{|l|c|}
\hline 環境作用の程度を表す係数 $\beta_{e}$ & 0.8 \\
\hline コンクリートの材料係数 $\gamma_{c}$ & 1.0 \\
\hline $\begin{array}{l}\text { 中性化速度係数の特性值 } \alpha_{k}=\alpha_{d} /\left(\beta_{e} \cdot \gamma_{c}\right) \mathrm{mm} / \\
\sqrt{y e a r}\end{array}$ & $\leqq 9.23$ \\
\hline 式(2)の精度に関する安全係数 $\gamma_{p \alpha}$ & 1.2 \\
\hline 中性化速度係数の予測值 $\alpha_{p} \leq \alpha_{k} / \gamma_{p \alpha} \mathrm{mm} / \sqrt{\text { year }}$ & $\leqq 7.69$ \\
\hline $\begin{array}{l}\text { 中性化速度係数の予測值を式(2)を用いて表層透 } \\
\text { 気係数に換算した数值 }\left(k T 28_{\mathrm{I}}\right) \times 10^{-16} \mathrm{~m}^{2}\end{array}$ & $\leqq 0.86$ \\
\hline 式(3)の精度に関する安全係数 $\gamma_{p k T}$ & 1.43 \\
\hline 式(4)の精度に関する安全係数 $\gamma_{p b l}$ & 1.1 \\
\hline ばらつきに関する安全係数 $\gamma_{\alpha T}$ & 1.25 \\
\hline 供試体と実構造物の差に関する安全係数 $\gamma_{c c}$ & 1.0 \\
\hline $\begin{array}{l}\text { 高さ方向の変動が無い場合の表層透気係数 } \\
\left(k T 28_{s}\right) \times 10^{-16} \mathrm{~m}^{2}\end{array}$ & $\leqq 0.48$ \\
\hline
\end{tabular}

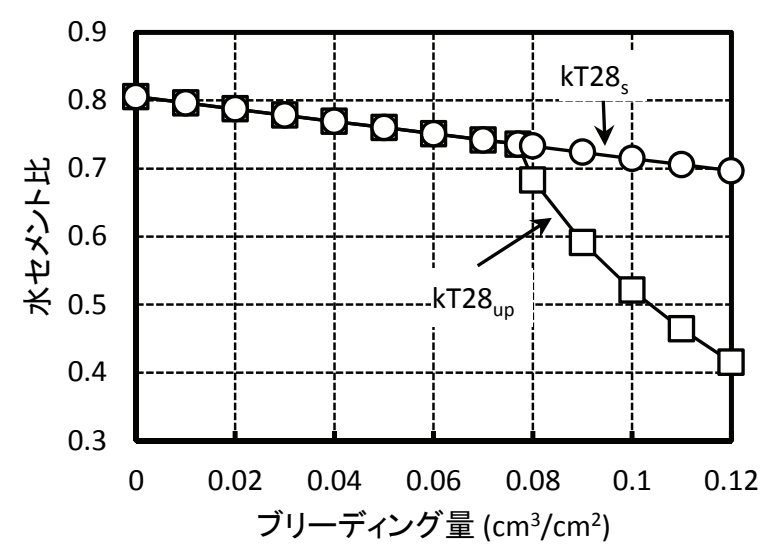

図-15 条件を満たす計算結果

求めた実験定数を違う材齡で算出すれば，他の材齢での 検査も可能になると思われる. 何れにしても，これらの 実験定数を定めた材齢で検查を実施する場合, 計測日直 前に雨水等によって計測面に水が供給される場合は, か ぶりコンクリートの含水率が急激に変化し, 結果として 表層透気係数も変化すると考えられる. 著者らの検討結

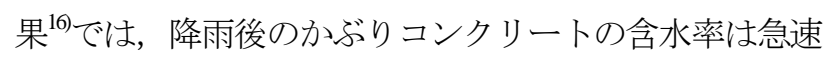
に増加するものの, 2日後には降雨前の含水状態に戻る ことを確認しており，検査実施に際しては，これらの影 響を考慮する必要がある. 例えば，検査日の前日に降雨 の可能性がある場合は, 降雨前日と降雨2日後の計測結 果に基づいて, 当該検査日の結果を推測することなどが 考えられる．測定した結果とkT28 を比較して，検査の 結果を判定することとなる.

測定結果と式(2)の精度に関する安全係数 $\gamma_{p \alpha}$ を用いて 実際に達成されたコンクリートの中性化速度係数の特性 值（初期性能）を把握し，この結果に基づいて中性化の 進行を予測し，維持管理計画に反映させることができる. 


\section{5. おわりに}

本研究では，中性化に伴う鋼材腐食において，表面透 気試験を用いた設計と検査の連係，および初期性能の把 握とその後の維持管理への活用に関して一つの考え方を 提案した，検討過程において，限られた条件ではあるが， 表層透気係数は水セメント比，ブリーディング量および 1層の打込み高さの関数として表現可能であることを示 した.

本文中で記載したとおり，本研究で対象としていない 要因が残されており，今後も継続して検討を進めていく 予定である.

謝辞 : 本研究の一部は，科研費（23360189）の助成を受 けたものである.

\section{参考文献}

1） 2007 年制定コンクリート標準示方書 [設計編］，土 木学会, 2008.

2) 松崎晋一朗, 吉田亮, 岸利治, 魚本健人：単位水量 を変えた角柱供試体における高さ方向の透気性変化 に関する一考察，第 36 回土木学会関東支部技術発表 会, V-35, 2009.3.

3) 早川健司, 加藤佳孝 : 材料分離がコンクリートの表 層透気性に及ぼす影響, コンクリート工学年次論文 集, Vol.33, No.1, pp.647-652, 2011.

4） 2007 年制定コンクリート標準示方書［施工編］，土 木学会, 2008.

5) コンクリート委員会示方書改訂小委員会報告書, 土 木学会, pp.16-17, 2010.5.

6) 岸利治：「ひび割れ制御と耐久設計」を活かすため に「品質」を問う，コンクリート工学，Vol.43，No.5, pp.75-80, 2005.5.

7) 氏家勲：実構造物におけるかぶりコンクリートの吸 水性, 透水性, 透気性の測定方法, コンクリート工 学, Vol.32, No.12, pp.43-47, 1994.

8）今本啓一, 下澤和幸, 山崎順二, 二村誠二 : 実構造 物の表層透気性の非・微破壊試験方法に関する研究 の現状, コンクリート工学, Vol.44, No.2, pp.31-38, 2006.2.

9) Torrent, R.: A two-chamber vacuum cell for measuring the coefficient of permeability to air the concrete cover on site, Materials and Structures, Vol.25, pp.358-365, 1992.

10) 土木学会：施工性能にもとづくコンクリートの配合 設計・施工指針（案）, コンクリートライブラリー 126, 2007.3.

11）早川健司, 加藤佳孝 : 振動締固めによるかぶりコン クリートの充填挙動と品質変動に関する実験的研究, コンクリート工学年次論文集, Vol.32, pp.1325-1330,
2010.7.

12) RILEM Publications S.A.R.L.: Non-Destructive Evaluation of thee Penetrability and Thickness of the Concrete Cover, State-of-the-Art Report of RILEM Technical Committee 189-NEC, RILEM Report40, p.49, 2007.5.

13) 小野聖久, 上東泰 : 非破壊試験による密実性評価と コンクリートの耐久性に関する考察，土木学会第 60 回年次学術講演会，5-259，2005.9.

14）今本啓一, 山㠃順二, 下澤和幸, 永山勝, 二村誠 二 : かぶりコンクリートの透気性に基づく $\mathrm{RC}$ 構造物 の耐久性能検証に向けた基礎的研究, 日本建築学会 構造系論文集，第 74 巻，第 638 号, pp.593-599, 2009.4.

15）白根勇二, 舟橋政司, 松尾健二：施工条件や養生条 件がコンクリート表層部の品質に及ぼす影響, コン クリート工学年次論文集, Vo1.32, No.1, pp.13131318, 2010.

16) 水上翔太, 早川健司, 加藤佳孝, 勝木太 : 含水状態 を考慮した構造体かぶりコンクリートの透気性評価, コンクリート工学年次論文集, Vol.33, No.1, pp.1829-1834, 2011.

17) 高田良章：コンクリートの中性化に及ぼす各種要因 と中性化進行予測に関する研究, 芝浦工業大学学位 論文，2008.9.

18）鉄筋コンクリート造建築物の耐久性設計施工指針 （案）・同解説, 日本建築学会, p.58, 2004.

19) 松田芳範, 上田洋, 石田哲也, 岸利治: 実構造物調 査に基づく中性化に与えるセメントおよび水分の影 響, コンクリート工学年次論文集, Vol.32, No.1, pp.629-634, 2010.

20）和泉意登志：コンクリートの中性化速度に基づく鉄 筋コンクリート造建築物の耐久設計手法に関する研 究, 大阪大学学位論文, 1991.12.

21) 吉田亮, 高松俊介, 秋山仁志, 岸利治 : 水セメント 比および単位水量がコンクリート表層の透気性に与 える影響の養生依存性に関する一考察, コンクリー 卜技術シリーズ No.80, pp.379-382, 2008.

22) 犬飼利嗣, 畑中重光, 三島直生, 金子林爾: 視覚的 評価方法によるコンクリート中のブリーディング挙 動に関する基礎的研究, コンクリート工学年次論文 集, Vo1.26, No.1, pp.609-614, 2004.

23) 早川健司：構造体かぶりコンクリートの品質管理に 関する研究, 東京大学学位論文, 2011.

24) 蔵重勲, 西田孝弘, 秋山仁志, 岸利治：中規模柱試 験体を対象とした非破壊評価による表層品質の要因 分析, コンクリート工学年次論文集, Vol.33, No.1, pp.1835-1840, 2011.

25) 豊村恵理, 松嵉晋一朗, 伊代田岳史 : 養生方法およ びその期間を考慮した中性化速度式に関する一検討, 土木学会第 66 回年次学術講演会概要集, pp.567-568, 2011.

(2011. 11. 7 受付) 


\section{A STUDY ON LINKAGE BETWEEN DURABILITY DESIGN AND INSPECTION SYSTEM FOR CARBONATION-CORRODED REINFORCEMENT BASED ON THE AIR PERMEABILITY TEST OF SURFACE CONCRETE}

\section{Yoshitaka KATO and Kenji HAYAKAWA}

In this research, the relationship between the results of the non-destructive surface air permeability test and the carbonation rate of concrete was examined in order to facilitate smooth information processing from the design stage to the construction, inspection, and maintenance stage. Corrosion of reinforcement due to carbonation was set as the cause of deterioration of the concrete structure. Although the examined experimental conditions were limited, the coefficient of air permeability of surface concrete can be formulated as a function of water-cement ratio, amount of bleeding water, and placement height per layer. The mix proportioning method, inspection system, and initial performance of structural concrete based on the proposed method are discussed. 